Full Length Article

\title{
Diagnostic accuracy of D-dimer in patients at high-risk for splanchnic vein thrombosis: A systematic review and meta-analysis
}

\author{
Nicoletta Riva $^{\text {a, *, Laura Maria Attard }}{ }^{\mathrm{b}}$, Kevin Vella ${ }^{\mathrm{c}}$, Alessandro Squizzato ${ }^{\mathrm{d}}$, Alex Gatt ${ }^{\mathrm{a}, \mathrm{c}}$, \\ Jean Calleja-Agius ${ }^{b}$
}

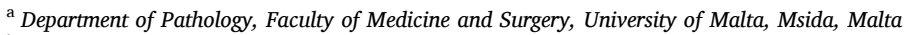

${ }^{\mathrm{b}}$ Department of Anatomy, Faculty of Medicine and Surgery, University of Malta, Msida, Malta

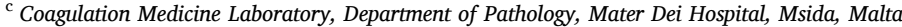

${ }^{\mathrm{d}}$ Department of Medicine and Surgery, University of Insubria, Como, Italy

\section{A R T I C L E I N F O}

\section{Keywords:}

Fibrin fibrinogen degradation products

Liver cirrhosis

Splanchnic circulation

Systematic review

Venous thrombosis

\begin{abstract}
A B S T R A C T
Background: D-dimer is included in the diagnostic algorithm for deep vein thrombosis and pulmonary embolism. However, its role in the diagnosis of splanchnic vein thrombosis (SVT) is still controversial. The aim of this study was to evaluate the diagnostic accuracy of D-dimer for SVT.

Methods: We performed a systematic review of the literature with meta-analysis (PROSPERO protocol registration number: CRD42020184300). The electronic databases MEDLINE, EMBASE, and CENTRAL were searched from inception to March 2021 week 4. Studies which evaluated D-dimer accuracy for SVT in any category of patients were selected. The index test was any D-dimer assay; the reference standard was any radiological imaging. The QUADAS-2 checklist was used for the risk of bias assessment. A bivariate random-effects regression model was used to calculate summary estimates of sensitivity and specificity.

Results: 12 studies (with a total of 1298 patients) evaluating the accuracy of D-dimer in patients at high risk of SVT (surgical patients, patients with liver cirrhosis or hepatocellular carcinoma) were included. None of the included studies was at low risk of bias. The weighted mean prevalence of SVT was 33.4\% (95\% CI, 22.5-45.2\%, $\mathrm{I}^{2}=94.8 \%$ ). D-dimer accuracy was expressed by sensitivity 96\% (95\% CI, 72-100\%); specificity 25\% (95\% CI, 5-67\%); positive likelihood ratio 1.3 (95\% CI, 0.9-1.9); negative likelihood ratio 0.16 (95\% CI, 0.03-0.84); area under the ROC curve 0.80 (95\% CI, 0.76-0.83).

Conclusions: D-dimer seems to have high sensitivity in the diagnosis of patients at high-risk for SVT. However, there is a strong need for more robust evidence on this topic.
\end{abstract}

\section{Introduction}

D-dimer is a marker of coagulation and fibrinolysis activation and it is elevated in patients with venous thromboembolism (VTE) [1]. It has a high sensitivity and negative predictive value, meaning that a negative D-dimer in patients with low/intermediate pre-test clinical probability can exclude the presence of acute VTE [2]. Nonetheless, it is not specific for VTE, thus confirmatory imaging is required. In fact, D-dimer can be increased in several other conditions, such as infections, cancer, trauma, recent surgery, liver cirrhosis, atrial fibrillation and pregnancy [3].

D-dimer has been included in the diagnostic algorithms for suspected pulmonary embolism (PE) [2], and deep vein thrombosis (DVT) of the lower [4,5] or upper extremities [6]. The association of D-dimer and clinical pre-test probability scores can potentially avoid imaging in approximately a third of patients with suspected PE [2]. A meta-analysis of patients with suspected cerebral vein thrombosis reported an overall good accuracy also in this setting, with D-dimer showing a sensitivity of $93.9 \%$ and a specificity of $89.7 \%$ [7]. Conversely, the role of D-dimer in the diagnosis of splanchnic vein thrombosis (SVT) is debated, mainly because several conditions predisposing to SVT are also associated with increased D-dimer.

SVT refers to thrombosis of the portal, mesenteric, splenic or hepatic veins. Since the main risk factors for SVT include liver cirrhosis, solid cancer, myeloproliferative neoplasm, abdominal surgery and abdominal

\footnotetext{
* Corresponding author at: Department of Pathology, Faculty of Medicine and Surgery, University of Malta, Msida MSD2080, Malta.

E-mail addresses: nicoletta.riva@um.edu.mt (N. Riva), laura.m.attard.16@um.edu.mt (L.M. Attard), kevin.c.vella@gov.mt (K. Vella), alessandro.squizzato@ uninsubria.it (A. Squizzato), alexander.gatt@um.edu.mt (A. Gatt), jean.calleja-agius@um.edu.mt (J. Calleja-Agius).
} 
inflammation/infections [8], the development of abdominal symptoms in these categories of patients should raise the suspicion of SVT. However, there are no clinical algorithms for SVT and the diagnosis currently relies on imaging, such as abdominal ultrasound (US), computed tomography (CT) or magnetic resonance (MR) [9]. A prompt identification of SVT is crucial to avoid the potentially life-threating outcomes, such as bowel infarction or severe portal hypertension with gastroesophageal variceal bleeding. In recent years, some studies evaluated the use of Ddimer in this setting with contrasting results [10]. The aim of this systematic review and meta-analysis was to estimate the accuracy of Ddimer for the diagnosis of SVT.

\section{Methods}

The protocol of this systematic review was developed and registered prospectively in the International Prospective Register of Systematic Reviews (PROSPERO registration number: CRD42020184300). This systematic review is reported according to the Preferred Reporting Items for a Systematic Review and Meta-analysis of Diagnostic Test Accuracy (PRISMA-DTA) Checklist [11].

\subsection{Study identification}

We tried to identify all studies that evaluated the diagnostic accuracy of D-dimer in SVT. A systematic search was performed using the electronic databases MEDLINE, EMBASE and Cochrane Central Register of Controlled Trials (CENTRAL) from inception to March 2021, week 4. The search strategy was developed without any language restriction and included the free text words and MeSH/EMTREE terms reported in Appendix S1. This search was supplemented by manual review of the reference lists of retrieved articles and previous systematic reviews/ meta-analysis on this topic (snowballing).

In order to identify unpublished studies reported in the grey literature, the abstract books from the congresses of the International Society on Thrombosis and Haemostasis (ISTH, years 2016-2020) and the International Society for Laboratory Hematology (ISLH, years 2016-2019) were hand-searched.

\subsection{Study selection}

Studies that fulfilled all the following criteria were included: 1) prospective or retrospective cohort studies, or cross-sectional studies; 2) patients with clinical suspicion of SVT, patients at low-risk of SVT (e.g. a general population of patients attending the Emergency Department) or patients at high-risk of SVT (defined as patients with at least one major risk factors for SVT: liver cirrhosis, abdominal surgery, abdominal inflammation/infections, myeloproliferative neoplasms or solid cancer); 3) SVT diagnosis objectively confirmed or ruled out by the following imaging tests, i.e. reference standard test: abdominal US, CT, MR, angiography, or abdominal surgery; 4) evaluation of any D-dimer assay, i.e. index test, for the diagnosis of SVT; 5) sensitivity and specificity of Ddimer for SVT was available or could be calculated. We excluded casereports, editorials, animal studies, studies conducted in children, studies evaluating VTE at other locations or the prognostic value of Ddimer, and studies which had less than 10 patients with SVT together with available D-dimer results.

After duplicate citations were removed, two authors (LMA, KV) independently reviewed titles and abstracts based on the inclusion/ exclusion criteria. The full-text versions of the papers deemed eligible by at least one of the two authors were retrieved. The same two authors reviewed the full-text articles and those meeting the prespecified selection criteria were chosen. Any disagreements were solved by discussion with a third author (NR).

\subsection{Data extraction}

From each paper two authors (LMA, KV) independently extracted the following information using a standardised form (developed as a Microsoft Excel spreadsheet): study characteristics (publication year, study design), patients characteristics (number of patients, demographics, inclusion and exclusion criteria), details of the reference standard test (type of imaging), details of the index test (D-dimer assay, cut-off, sensitivity, specificity, true positive [TP], true negative [TN], false positive [FP], false negative [FN]), interval between the index and the reference standard test. Any disagreements were solved by discussion with a third author (NR). If data regarding sensitivity and specificity were missing or unclear, the authors of the primary studies were emailed, with a reminder after 2 weeks. We obtained further information from 5 authors out of 11 studies with unclear or missing data.

\subsection{Risk of bias assessment}

Two authors (NR, AS) independently assessed risk of bias of the included studies using the Quality Assessment of Diagnostic Accuracy Studies 2 (QUADAS-2) checklist [12], with disagreements solved by consensus. The QUADAS-2 checklist assesses 4 domains with regards to the risk of bias (patient selection, index test, reference standard, flow and timing) and 3 domains with regards to concerns about applicability (patient selection, index test, reference standard) [12].

Since none of the retrieved primary studies evaluated D-dimer accuracy in a general population of patients at low risk of SVT, the QUADAS-2 checklist was adapted to patients at high risk of SVT and applied separately for the 3 main subgroups: a) patients with liver cirrhosis; b) patients with hepatocellular carcinoma (HCC); and c) postsurgical patients. The index test (D-dimer) was considered at low risk of bias if at least one prespecified threshold or the manufacturer's threshold were applied. Since the D-dimer is a laboratory quantitative test, we did not consider whether its interpretation was performed without knowledge of the reference standard results. Among the accepted reference standard imaging tests, US Doppler was considered at low risk of bias for diagnosing portal or splenic vein thrombosis, while CT and MR scan were considered at low risk of bias for all possible SVT locations, since they are both recommended to assess eventual extension into the mesenteric veins [13]. The time interval between the index test and the reference standard was considered acceptable if they were performed on the same day. Studies were classified at low risk of bias if all 4 domains of risk of bias were judged at low risk, and studies were classified at low concerns of applicability if all 3 domains of applicability concerns were judged at low risk.

\subsection{Statistical analysis}

Prevalence of SVT in the included primary studies was calculated as a weighted mean proportion with $95 \%$ confidence interval (95\% CI), using a random-effects model. For studies with multiple publications, we extracted data from the most recent publication. Statistical heterogeneity was evaluated using the $\mathrm{I}^{2}$ statistic, with values $0-40 \%$ representing irrelevant, 30-60\% moderate, $50-90 \%$ substantial and $75-100 \%$ considerable heterogeneity [14].

In order to evaluate D-dimer accuracy, we used a bivariate randomeffects regression model to calculate summary estimates of its sensitivity and specificity. This model assumes that the logit-transformed sensitivities and specificities of the primary studies follow a bivariate normal distribution around a mean value, and incorporates any correlation between sensitivity and specificity within studies [15]. Thus, in each primary study, the number of patients with positive D-dimer among all patients with SVT, as well as the number of patients with negative Ddimer among all patients without SVT, were assumed to follow a binomial distribution. Forest plots for the sensitivity and specificity of each primary study were created. We plotted a hierarchical summary receiver 


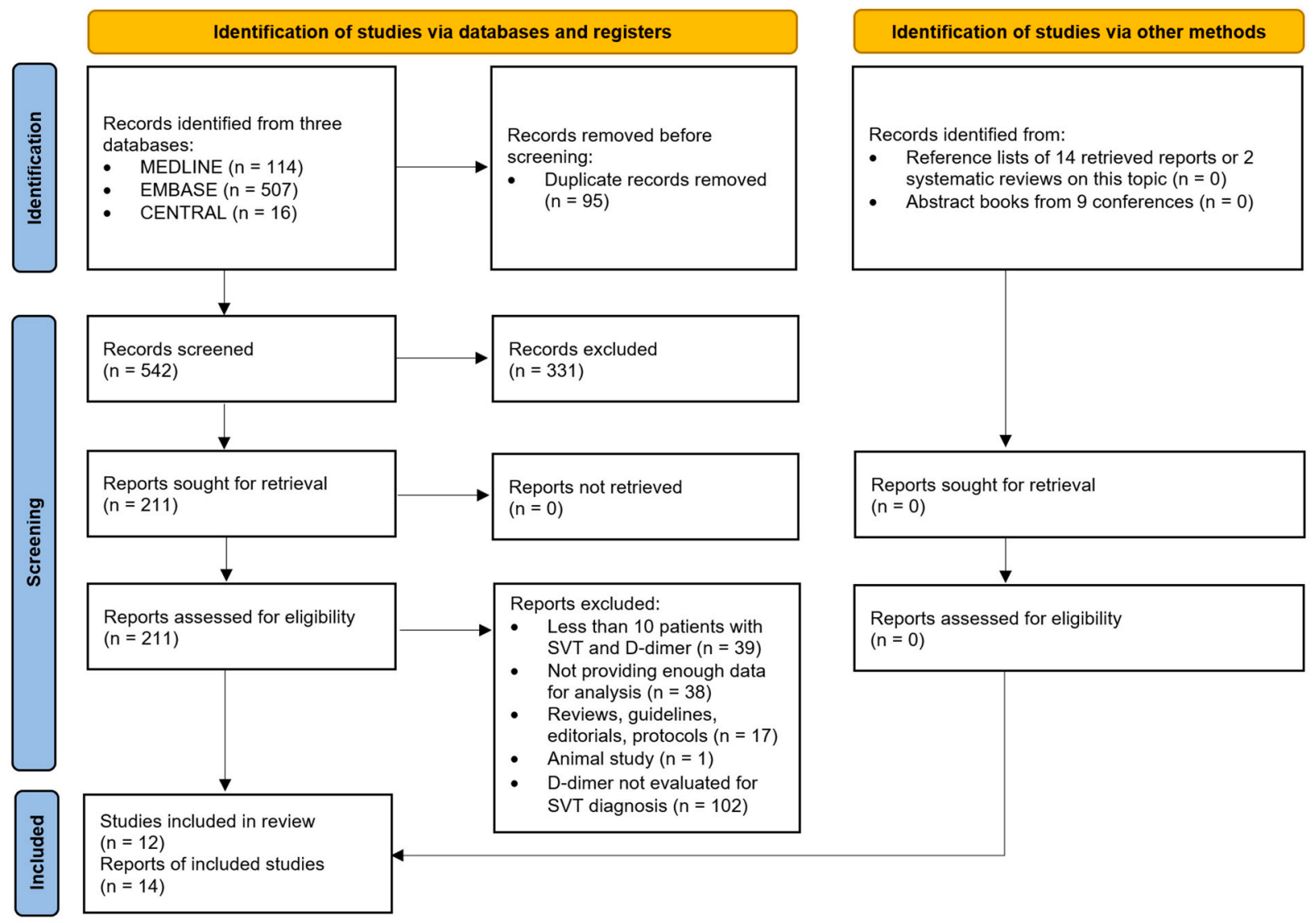

From: Page MJ, McKenzie JE, Bossuyt PM, Boutron I, Hoffmann TC, Mulrow CD, et al. The PRISMA 2020 statement: an updated guideline for reporting systematic reviews. BMJ 2021;372:n71. doi: 10.1136/bmj.n71. For more information, visit: http://www.prisma-statement.org/

Fig. 1. PRISMA 2020 flow diagram.

operating characteristic (ROC) curve, which displays the summary point, its $95 \%$ confidence region, and a $95 \%$ prediction region for the sensitivity and specificity of the index test in a future study [16].

We assumed the pre-test probability to be the weighted mean prevalence of SVT in the included primary studies. We graphically represented the relationship between pre-test and post-test probability using the Fagan plot (which shows the post-test probability based on pre-test probability and likelihood ratios) [17] and the probability-modifying plot (which provides separate curves for positive and negative test results). The unconditional negative predictive value (NPV) and positive predictive value (PPV) were also calculated.

The main statistical analysis was performed including all studies that provided sensitivity and specificity of D-dimer. If more than one D-dimer cut-off was reported, we used data regarding the manufacturer's cut-off or, if this was not available, the cut-off associated with the highest sensitivity.

Since there were no studies at low risk of bias, the prespecified sensitivity analysis could not be performed. However, a sensitivity analysis was done by including only studies with low concerns of applicability. In order to explore possible causes of heterogeneity, multiple subgroup analyses and multiple univariable meta-regression analyses of sensitivity and specificity were performed by considering characteristics of the population (patients undergoing surgical procedures vs non-surgical patients), degree of liver dysfunction (Child-Pugh classes A, B, C), reference standard imaging (US vs CT/MR), D-dimer assay (ELISA/immunofiltration assays vs latex enhanced/immunoturbidimetric assays), D-dimer threshold (manufacturer's vs optimal cutoff), applicability concerns (low vs high).

The presence of publication bias was assessed through the creation of the Deeks' funnel plot, which displays the diagnostic odds ratio on the horizontal axis and the inverse of the square root of the effective sample size on the vertical axis [18].

Statistical analysis was performed using the software STATA/BE version 17 (StataCorp LP, College Station, Texas, USA), with the userwritten commands metandi [16] and midas [19]. Since at least 4 studies are required to perform the meta-analysis using these commands, sub-analyses with less than 4 studies were performed using the software Meta-DiSc version 2.0 (Universidad Complutense, Madrid, Spain) [20]. $P$ values $<0.05$ were considered statistically significant.

\section{Results}

\subsection{Study identification and selection}

We identified 637 potentially relevant citations (114 from MEDLINE, 507 from EMBASE and 16 from CENTRAL); 95 citations were duplicate, while 331 were excluded after screening the title and abstract using the predefined inclusion and exclusion criteria. Thus, 211 studies were retrieved in full text for detailed evaluation. Among these, 197 studies were excluded after full text evaluation (the rationale for exclusion is provided in the PRISMA flow diagram, Fig. 1, while the citations of the excluded articles are available upon request). Finally, 12 studies were included in this systematic review [21-32], since 2 patients cohorts were reported in more than one publication [33,34]. No additional studies were identified from the reference lists of the 14 retrieved reports, from 2 systematic review published on this topic $[10,35]$ and from searching into the grey literature. 
Table 1

Characteristics of the included studies.

\begin{tabular}{|c|c|c|c|c|c|c|c|c|}
\hline Author, year & Study design & Study aim & Years & Inclusion criteria & Exclusion criteria & $\begin{array}{l}\text { N. of } \\
\text { patients }\end{array}$ & $\begin{array}{l}\text { Sex: } \\
\text { M/F }\end{array}$ & $\begin{array}{l}\text { Age } \\
\text { (years) }\end{array}$ \\
\hline $\begin{array}{l}\text { Fimognari, } \\
2005 \text { [21] }\end{array}$ & NR & $\begin{array}{l}\text { To investigate the } \\
\text { behaviour of D-dimer and } \\
\text { FVIII in cirrhotic patients } \\
\text { with and without PVT and } \\
\text { their specificity and } \\
\text { sensitivity in detecting } \\
\text { PVT }\end{array}$ & NR & $\begin{array}{l}\text { Consecutive cirrhotic } \\
\text { patients with stable } \\
\text { cirrhosis }\end{array}$ & $\begin{array}{l}\text { HCC, cholestatic liver } \\
\text { diseases, previous } \\
\text { abdominal surgery, } \\
\text { pancreatitis, or recent } \\
\text { abdominal trauma }\end{array}$ & $\begin{array}{l}136 \text { (\& } 38 \\
\text { healthy } \\
\text { controls) }\end{array}$ & $\begin{array}{l}87 / \\
49\end{array}$ & $\begin{array}{l}59 \\
\text { (mean) }\end{array}$ \\
\hline $\begin{array}{l}\text { Stamou, } 2006 \\
\quad[22]\end{array}$ & $\begin{array}{l}\text { Prospective } \\
\text { observational }\end{array}$ & $\begin{array}{l}\text { To determine the exact } \\
\text { incidence of } \\
\text { postsplenectomy } \\
\text { extrahepatic portal system } \\
\text { thrombosis and to identify } \\
\text { controllable risk factors }\end{array}$ & $\begin{array}{l}\text { Feb 1999- } \\
\text { Dec } 2003\end{array}$ & $\begin{array}{l}\text { Consecutive patients who } \\
\text { underwent splenectomy } \\
\text { (patients at mild or severe } \\
\text { risk of thrombosis received } \\
\text { prophylactic low molecular } \\
\text { weight heparin) }\end{array}$ & Early post-operative death & 146 & $\begin{array}{l}84 / \\
62\end{array}$ & $\begin{array}{l}47 \\
\text { (mean) }\end{array}$ \\
\hline $\begin{array}{l}\text { Deng, } 2007 \\
{[23]}\end{array}$ & Prospective & $\begin{array}{l}\text { To evaluate the predictive } \\
\text { value of D-dimer as a } \\
\text { predictive indicator of } \\
\text { PVT after PHT surgery in } \\
\text { hepatitis B virus-related } \\
\text { cirrhosis }\end{array}$ & $\begin{array}{l}\text { Sept 2004- } \\
\text { Mar } 2006\end{array}$ & $\begin{array}{l}\text { Patients diagnosed with } \\
\text { PHT due to liver cirrhosis } \\
\text { (hepatitis B) who } \\
\text { underwent splenectomy } \\
\text { (with/without } \\
\text { gastroesophageal } \\
\text { devascularization, or } \\
\text { endoscopic variceal } \\
\text { ligation) }\end{array}$ & $\begin{array}{l}\text { Patients who underwent } \\
\text { PHT shunting surgery, } \\
\text { liver transplant patients, } \\
\text { patients having concurrent } \\
\text { liver cirrhosis and HCC, } \\
\text { patients diagnosed with } \\
\text { PVT before surgery }\end{array}$ & 52 & $46 / 6$ & $\begin{array}{l}46 \\
\text { (median) }\end{array}$ \\
\hline $\begin{array}{l}\text { Wang, } 2010 \\
\text { [24] }\end{array}$ & Prospective & $\begin{array}{l}\text { To investigate the } \\
\text { predictive value of } \\
\text { combined use of D-dimer } \\
\text { and P-selectin for splenic } \\
\text { or PVT after splenectomy }\end{array}$ & $\begin{array}{l}\text { Aug } \\
2006-2008\end{array}$ & $\begin{array}{l}\text { Patients with hepatic } \\
\text { cirrhosis-related PHT who } \\
\text { underwent splenectomy } \\
\text { (with/without } \\
\text { gastroesophageal } \\
\text { devascularization) }\end{array}$ & $\begin{array}{l}\text { Presence of other chronic } \\
\text { illness such as } \\
\text { cardiovascular, respiratory } \\
\text { or renal disease, systemic } \\
\text { coagulation disorders, } \\
\text { history of splenic or PVT } \\
\text { prior to surgery }\end{array}$ & 82 & $\begin{array}{l}51 / \\
31\end{array}$ & $\begin{array}{l}51 \\
\text { (mean) }\end{array}$ \\
\hline $\begin{array}{c}\text { Zhang, } 2013 \\
{[25,33]}\end{array}$ & NR & $\begin{array}{l}\text { To investigate the value of } \\
\text { D-dimer and protein S } \\
\text { plasma concentrations as } \\
\text { potential biomarkers for } \\
\text { diagnosis of PVT in } \\
\text { patients with liver } \\
\text { cirrhosis }\end{array}$ & $\begin{array}{l}\text { Jan 2008- } \\
\text { Jan } 2011\end{array}$ & $\begin{array}{l}\text { Patients with liver cirrhosis } \\
\text { caused by hepatitis B, } \\
\text { hepatitis C or alcoholism }\end{array}$ & $\begin{array}{l}\text { Presence of liver cancer, } \\
\text { endoscopic therapy, } \\
\text { splenectomy, autoimmune } \\
\text { disease, other } \\
\text { malignancies, liver } \\
\text { cirrhosis due to } \\
\text { autoimmune hepatitis or } \\
\text { primary biliary cirrhosis }\end{array}$ & 188 & $\begin{array}{l}142 / \\
46\end{array}$ & $\begin{array}{l}58 \\
\text { (mean) }\end{array}$ \\
\hline Dai, 2015 [26] & $\begin{array}{l}\text { Retrospective } \\
\text { observational }\end{array}$ & $\begin{array}{l}\text { To explore the association } \\
\text { between D-dimer levels } \\
\text { and presence of portal } \\
\text { venous system thrombosis } \\
\text { in liver cirrhosis }\end{array}$ & $\begin{array}{l}\text { Jul 2011- } \\
\text { Jun } 2014\end{array}$ & $\begin{array}{l}\text { All consecutive patients } \\
\text { with 1) diagnosis of liver } \\
\text { cirrhosis; 2) no malignancy, } \\
\text { especially HCC; 3) D-dimer } \\
\text { tests; 4) contrast-enhanced } \\
\text { CT and/or MR to evaluate } \\
\text { the vessel patency within } \\
\text { the portal venous system }\end{array}$ & NR & 66 & $\begin{array}{l}43 / \\
23\end{array}$ & $\begin{array}{l}54 \\
\text { (mean) }\end{array}$ \\
\hline $\begin{array}{r}\text { Fei, } 2016 \\
{[27,34]}\end{array}$ & Retrospective & $\begin{array}{l}\text { To evaluate the value of D- } \\
\text { dimer, P-selectin, and } \\
\text { platelet count in patients } \\
\text { with cirrhotic PHT for } \\
\text { prediction of PVT after } \\
\text { devascularization }\end{array}$ & $\begin{array}{l}\text { Jan 2012- } \\
\text { Apr } 2014\end{array}$ & $\begin{array}{l}\text { Consecutive patients with } \\
\text { hepatitis virus-related } \\
\text { cirrhosis with PHT who } \\
\text { underwent } \\
\text { devascularization }\end{array}$ & $\begin{array}{l}\text { Serious cardiopulmonary } \\
\text { diseases, chronic duodenal } \\
\text { ulcers, or patients whose } \\
\text { serum levels of D-dimer, P- } \\
\text { selectin, or platelet count } \\
\text { during the time of } \\
\text { diagnosis and treatment } \\
\text { were not available, } \\
\text { patients who may have } \\
\text { been taking warfarin or } \\
\text { aspirin }\end{array}$ & 137 & $\begin{array}{l}80 / \\
57\end{array}$ & $\begin{array}{l}46 \\
\text { (mean) }\end{array}$ \\
\hline $\begin{array}{l}\text { Wosiewicz, } \\
2016 \text { [28] }\end{array}$ & NR & $\begin{array}{l}\text { To examine endotoxemia } \\
\text { in cirrhotic patients who } \\
\text { developed PVT and its } \\
\text { relationship to zonulin } \\
\text { serum level and laboratory } \\
\text { parameters defining } \\
\text { coagulation system }\end{array}$ & NR & $\begin{array}{l}\text { Patients with cirrhosis of } \\
\text { mixed etiology, aged } 27 \text { to } \\
81 \text { years, hospitalised for } \\
\text { endoscopic prophylaxis of } \\
\text { esophageal variceal } \\
\text { bleeding or deterioration of } \\
\text { their clinical status }\end{array}$ & $\mathrm{NR}$ & 49 & $\begin{array}{l}34 / \\
15\end{array}$ & $\begin{array}{l}27-81 \\
\text { (range) }\end{array}$ \\
\hline $\begin{array}{c}\text { Malaguarnera, } \\
2018 \text { [29] }\end{array}$ & Observational & $\begin{array}{l}\text { To investigate whether D- } \\
\text { dimer testing could be a } \\
\text { sensitive marker in HCC } \\
\text { patients for the diagnosis } \\
\text { of PVT and for the } \\
\text { prognosis }\end{array}$ & $\begin{array}{l}\text { Jun } 2010- \\
\text { Dec } 2015\end{array}$ & $\begin{array}{l}\text { Patients with clinical and/ } \\
\text { or histologically proven } \\
\text { HCC with or without } \\
\text { cirrhosis }\end{array}$ & $\begin{array}{l}\text { Patients with 1) significant } \\
\text { metabolic, renal, or } \\
\text { gastrointestinal disease; 2) } \\
\text { coagulation problem; 3) } \\
\text { history of acute peptic } \\
\text { ulcer disease; 4) collagen } \\
\text { disease, chronic infections }\end{array}$ & $\begin{array}{l}118 \text { HCC } \\
\text { ( \& } 50 \\
\text { healthy } \\
\text { controls) }\end{array}$ & $\begin{array}{l}69 / \\
49\end{array}$ & $\begin{array}{l}70 \\
\text { (median) }\end{array}$ \\
\hline Wei, 2018 [30] & Retrospective & $\begin{array}{l}\text { To investigate the changes } \\
\text { in P-selectin, thrombus } \\
\text { precursor protein, and D- }\end{array}$ & $\begin{array}{l}\text { Jan 2009- } \\
\text { Dec } 2016\end{array}$ & $\begin{array}{l}\text { Patients with cirrhotic PHT } \\
\text { who underwent }\end{array}$ & $\begin{array}{l}\text { Age }>70 \text { or }<20 \text { years old; } \\
\text { no typical manifestations } \\
\text { of PHT or hepatic venous }\end{array}$ & 144 & $\begin{array}{l}66 / \\
78\end{array}$ & $\begin{array}{l}52 \\
\text { (mean) }\end{array}$ \\
\hline
\end{tabular}


Table 1 (continued)

\begin{tabular}{|c|c|c|c|c|c|c|c|c|}
\hline Author, year & Study design & Study aim & Years & Inclusion criteria & Exclusion criteria & $\begin{array}{l}\text { N. of } \\
\text { patients }\end{array}$ & $\begin{array}{l}\text { Sex: } \\
M / F\end{array}$ & $\begin{array}{l}\text { Age } \\
\text { (years) }\end{array}$ \\
\hline & & $\begin{array}{l}\text { dimer in patients with } \\
\text { cirrhosis after portal } \\
\text { hypertensive splenectomy } \\
\text { and explore its values on } \\
\text { the prediction of } \\
\text { postoperative PVT } \\
\text { formation }\end{array}$ & & $\begin{array}{l}\text { splenectomy (with/without } \\
\text { devascularization) }\end{array}$ & $\begin{array}{l}\text { pressure gradient } \leq 5 \\
\text { mmHg; incomplete } \\
\text { clinicopathologic data; } \\
\text { recent treatment with } \\
\text { nonselective b-blocker } \\
\text { drugs; deteriorated liver } \\
\text { function or aspartate } \\
\text { transaminase }>5 \text { times of } \\
\text { the upper limit, or serum } \\
\text { bilirubin } \geq 5 \text { mg/dL; } \\
\text { cardiovascular, brain, } \\
\text { lung, kidney, and other } \\
\text { severe organic disease; } \\
\text { hematopoietic system } \\
\text { diseases, severe } \\
\text { coagulation disorders, } \\
\text { congenital thrombotic } \\
\text { disease, preoperative PVT, } \\
\text { or congenital portal vein } \\
\text { malformations }\end{array}$ & & & \\
\hline Guo, 2019 [31] & Retrospective & $\begin{array}{l}\text { To investigate the platelet } \\
\text { change after splenectomy } \\
\text { and its correlation with } \\
\text { the formation of portal } \\
\text { vein system thrombosis }\end{array}$ & $\begin{array}{l}\text { Aug 2014- } \\
\text { Jun } 2018\end{array}$ & $\begin{array}{l}\text { Patients with cirrhotic PHT } \\
\text { and hypersplenism, } \\
\text { preoperative Child-Pugh } \\
\text { score A or B, who } \\
\text { underwent splenectomy }\end{array}$ & $\begin{array}{l}\text { Patients with preoperative } \\
\text { Child-Pugh score C, severe } \\
\text { heart, lung, liver, and } \\
\text { kidney dysfunction who } \\
\text { cannot tolerate surgery }\end{array}$ & 117 & $\begin{array}{l}58 / \\
59\end{array}$ & $\begin{array}{l}29 \\
\text { (mean) }\end{array}$ \\
\hline $\begin{array}{l}\text { Takata, } 2021 \\
\text { [32] }\end{array}$ & Retrospective & $\begin{array}{l}\text { To evaluate the incidence } \\
\text { of PVT after hepatectomy } \\
\text { for HCC and identify } \\
\text { coagulation and } \\
\text { fibrinolytic factors that } \\
\text { could predict early-stage } \\
\text { postoperative PVT }\end{array}$ & $\begin{array}{l}\text { Dec 2014- } \\
\text { Sept } 2019\end{array}$ & $\begin{array}{l}\text { Patients with HCC who } \\
\text { underwent radical } \\
\text { hepatectomy }\end{array}$ & $\begin{array}{l}\text { Patients unable to undergo } \\
\text { contrast-enhanced CT scan } \\
\text { because of renal } \\
\text { dysfunction, asthma, or } \\
\text { allergy to contrast agents }\end{array}$ & 65 & $\begin{array}{l}55 / \\
10\end{array}$ & $\begin{array}{l}73 \\
\text { (mean) }\end{array}$ \\
\hline
\end{tabular}

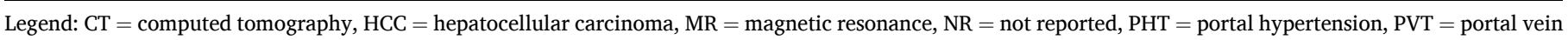
thrombosis.

\subsection{Study characteristics}

Characteristics of the included studies are summarised in Table 1, while details of the index and the reference standard tests are summarised in Table 2. The number of enrolled patients ranged from 49 patients [28] to 188 patients [25], for a total of 1298 patients.

None of the studies enrolled patients with clinically suspected SVT or patients at low risk of SVT. In fact, 7 studies enrolled patients undergoing surgical procedures (e.g. splenectomy, hepatectomy, or gastroesophageal devascularisation) [22-24,27,30-32], often in combination with other risk factors (such as liver cirrhosis [23,24, 27,30,31] or HCC [32]); 4 studies enrolled patients with liver cirrhosis only [21,25,26,28] and one study enrolled patients with HCC only [29]. In addition, 9 studies evaluated patients with different degree of liver dysfunction, as expressed by Child-Pugh classes A, B or C [21,23-26,28,30-32]; however, separate sensitivity and specificity data were available only in 7 of them $[21,23,25,26,28,31,32]$.

The reference standard imaging was Doppler US in 8 studies [21-24,27,29-31] and CT or MR scan in 4 studies $[25,26,28,32]$. Imaging tests and D-dimer were performed on the same day in 2 studies $[21,26]$. With the exception of one study that did not report details of the kits/reagents [22] and one study that used a semi-quantitative D-dimer assay [23], the others used quantitative D-dimer assays (5 latex enhanced immunoassays or immunoturbidimetric assays [21,27,30-32], 1 immunofiltration assay [26] and 4 enzyme-linked immunosorbent assays $[24,25,28,29])$. Eight studies used the manufacturers' D-dimer cut-offs [22-24,27,29-32], 3 studies used post-hoc optimal cut-offs $[21,25,28]$, and 1 study presented accuracy results with both the manufacturer's and an optimal cut-off [26].

\subsection{Risk of bias}

Risk of bias and applicability concerns of the included studies, divided into 3 categories (liver cirrhosis, HCC, and post-surgical patients), are summarised in Fig. 2, while the rationale for the risk of bias judgment is reported in Appendix S2.

The risk of bias for patient selection was high in 9 studies which did not enrol consecutive patients or used inappropriate exclusions [23-25,27-32]. The risk of bias for the index test was high in 3 studies which assessed only post-hoc D-dimer thresholds [21,25,28]. The risk of bias for the reference standard was high in 5 studies which used Doppler US to assess thrombosis in the portal venous system, including mesenteric vein $[21-23,30,31]$. The risk of bias for flow and timing was high in 8 studies which did not perform reference standard and index test on the same day [22-25,27,30-32].

None of the included studies was at low risk of bias in all domains, while 5 studies were at low risk of concerns of applicability $[24,26,27,29,32]$.

\subsection{Synthesis of results}

Data regarding the sensitivity and specificity of D-dimer and the number of FN, TP, TN, FP in each study are summarised in Appendix S3.

\subsubsection{Prevalence of splanchnic vein thrombosis in high-risk patients}

The weighted mean prevalence of SVT, calculated from 12 studies [21-32], was 33.4\% (95\% CI, 22.5-45.2\%; 445/1298 patients) and heterogeneity was considerable $\left(\mathrm{I}^{2}=94.8 \%, p<0.001\right.$, Fig. 3$)$.

In detail, in patients undergoing surgery the weighted mean prevalence of SVT was $33.1 \%$ (95\% CI, 15.6-53.4\%; 263/743 patients; 7 studies; $\left.\mathrm{I}^{2}=96.8 \%, \mathrm{p}<0.001\right)$, while in non-surgical patients it was $33.6 \%$ (95\% CI, 24.6-43.2\%; 182/555 patients; 5 studies; $\mathrm{I}^{2}=80.6 \%$, $\mathrm{p}$ 
Table 2

Details of the tests used in the included studies.

\begin{tabular}{|c|c|c|c|c|c|c|c|}
\hline \multirow[t]{2}{*}{ Author, year } & \multicolumn{3}{|l|}{ Index test: D-dimer } & \multicolumn{3}{|c|}{ Reference standard } & \multirow{2}{*}{$\begin{array}{l}\text { Interval between } \\
\text { index test and } \\
\text { reference standard }\end{array}$} \\
\hline & Type of assay & $\begin{array}{l}\text { Cut-offs } \\
\text { (ng/mL) }\end{array}$ & Timing & $\begin{array}{l}\text { Site of } \\
\text { thrombosis }\end{array}$ & $\begin{array}{l}\text { Type of } \\
\text { imaging }\end{array}$ & Timing & \\
\hline $\begin{array}{l}\text { Fimognari, } 2005 \\
\quad[21]\end{array}$ & $\begin{array}{l}\text { Automated latex enhanced } \\
\text { immunoassay (Instrumentation } \\
\text { Laboratory Coagulation Systems ACL } \\
9000 \text { ) }\end{array}$ & $\begin{array}{l}225 \\
550\end{array}$ & NR & PVT & $\begin{array}{l}\text { Doppler } \\
\text { US }\end{array}$ & NR & Same day \\
\hline $\begin{array}{l}\text { Stamou, } 2006 \\
\quad[22]\end{array}$ & $\mathrm{NR}$ & $500^{\mathrm{a}}$ & $\begin{array}{l}\text { Pre-op \& post-op } \\
\text { days } 5,7 \text { and on } \\
\text { discharge }\end{array}$ & $\begin{array}{l}\text { Portal system } \\
\text { thrombosis }\end{array}$ & $\begin{array}{l}\text { Doppler } \\
\text { US }\end{array}$ & $\begin{array}{l}\text { Pre-op \& post-op days } \\
7,30\end{array}$ & NR \\
\hline Deng, 2007 [23] & $\begin{array}{l}\text { Semi-quantitative latex agglutination } \\
\text { (Shanghai Sun Company) }\end{array}$ & $\begin{array}{l}500^{\mathrm{a}} \\
1000 \\
2000 \\
4000 \\
8000 \\
16,000\end{array}$ & $\begin{array}{l}\text { Pre-op \& post-op } \\
\text { days } 1 \text { and } 5\end{array}$ & PVT & $\begin{array}{l}\text { Doppler } \\
\text { US }\end{array}$ & $\begin{array}{l}\text { From } 7 \text { to } 14 \text { days } \\
\text { postoperatively }\end{array}$ & NR \\
\hline Wang, 2010 [24] & $\begin{array}{l}\text { ELISA (Sunshine Bio Ltd., Shanghai, } \\
\text { China) }\end{array}$ & $500^{\mathrm{a}}$ & $\begin{array}{l}\text { Pre-op \& at the } \\
\text { day before each } \\
\text { Doppler US }\end{array}$ & Splenic or PVT & $\begin{array}{l}\text { Doppler } \\
\text { US }\end{array}$ & $\begin{array}{l}\text { Pre-op \& post-op days } \\
2,4,6,8,11,15,22\end{array}$ & 1 day \\
\hline $\begin{array}{l}\text { Zhang, } 2013 \\
{[25,33]}\end{array}$ & ELISA (Sun Biotech, Shanghai, China) & $\begin{array}{l}240 \\
560 \\
770 \\
920 \\
1180\end{array}$ & NR & PVT & CT & $\begin{array}{l}\text { Within } 48 \mathrm{~h} \text { following } \\
\text { patient admission }\end{array}$ & Within $48 \mathrm{~h}$ \\
\hline Dai, 2015 [26] & $\begin{array}{l}\text { Immunofiltration assay (NycoCard D- } \\
\text { dimer) }\end{array}$ & $\begin{array}{l}100 \\
220 \\
300^{\mathrm{a}} \\
900 \\
2160\end{array}$ & At admission & $\begin{array}{l}\text { Portal venous } \\
\text { system } \\
\text { thrombosis }\end{array}$ & $\mathrm{CT} / \mathrm{MR}$ & At admission & Same day \\
\hline $\begin{array}{r}\text { Fei, } 2016 \\
{[27,34]}\end{array}$ & $\begin{array}{l}\text { Automated latex enhanced } \\
\text { immunoassay (Instrumentation } \\
\text { Laboratory on Coagulation Systems ACL } \\
9000 \text { ) }\end{array}$ & $500^{\mathrm{a}}$ & $\begin{array}{l}\text { Day } 1 \text { pre-op \& } \\
\text { post-op days } 1,3 \text {, } \\
7,15\end{array}$ & PVT & $\begin{array}{l}\text { Doppler } \\
\text { US }\end{array}$ & $\begin{array}{l}\text { Day } 3 \text { pre-op } \& \text { post-op } \\
\text { days } 2,5,7,15,22,30\end{array}$ & NR \\
\hline $\begin{array}{l}\text { Wosiewicz, } 2016 \\
\text { [28] }\end{array}$ & $\begin{array}{l}\text { ELISA (IMU-CLONE, Seiksui American } \\
\text { Diagnostica Inc., Stanford, USA) }\end{array}$ & $\begin{array}{l}1820 \\
2470 \\
3380\end{array}$ & NR & PVT & CT & NR & NR \\
\hline $\begin{array}{l}\text { Malaguarnera, } \\
2018 \text { [29] }\end{array}$ & ELISA (no further details) & $300^{\mathrm{a}}$ & NR & PVT & $\begin{array}{l}\text { Doppler } \\
\text { US }\end{array}$ & NR & NR \\
\hline Wei, 2018 [30] & $\begin{array}{l}\text { Immunoturbidometry kit (Shanghai } \\
\text { Xisen Meikang Medical Electronics Co, } \\
\text { Ltd., Shanghai, China) }\end{array}$ & $500^{\mathrm{a}}$ & $\begin{array}{l}\text { Day } 1 \text { pre-op \& } \\
\text { post-op days } 1,3 \text {, } \\
5,7,14\end{array}$ & PVT & $\begin{array}{l}\text { Doppler } \\
\text { US }\end{array}$ & $\begin{array}{l}\text { From day } 1 \text { before } \\
\text { surgery to day } 14 \text { after } \\
\text { surgery }\end{array}$ & NR \\
\hline Guo, 2019 [31] & $\begin{array}{l}\text { Latex enhanced immunoturbidimetric } \\
\text { assay (Innovance D-dimer, Siemens) }\end{array}$ & $550^{\mathrm{a}}$ & $\begin{array}{l}\text { Pre-op \& post-op } \\
\text { days } 1,7,14\end{array}$ & $\begin{array}{l}\text { Portal vein } \\
\text { system } \\
\text { thrombosis }\end{array}$ & $\begin{array}{l}\text { Doppler } \\
\text { US }\end{array}$ & $\begin{array}{l}\text { Pre-op \& post-op } \\
\text { within } 7 \text { days, and day } \\
14\end{array}$ & NR \\
\hline $\begin{array}{l}\text { Takata, } 2021 \\
\text { [32] }\end{array}$ & $\begin{array}{l}\text { Latex enhanced immunoturbidimetric } \\
\text { assay (Nanopia D-dimer assay, Sekisui } \\
\text { Medical, Tokyo, Japan) }\end{array}$ & $1000^{\mathrm{a}}$ & $\begin{array}{l}\text { Pre-op \& post-op } \\
\text { days } 1,2,3\end{array}$ & PVT & CT & Pre-op \& post-op day 7 & NR \\
\hline
\end{tabular}

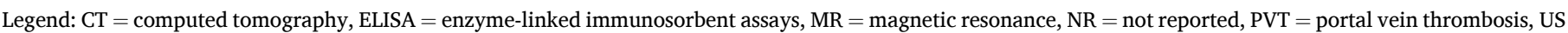
$=$ ultrasound.

a Manufacturers' cut-off.

$<0.001$; Appendix S4A). In patients with different degrees of liver dysfunction, the weighted mean prevalence of SVT in Child-Pugh class A was $34.7 \%$ (95\% CI, 21.2-49.5\%; 150/364 patients; 9 studies; $\mathrm{I}^{2}=$ 86.4\%, p < 0.001); in Child-Pugh class B 37.9\% (95\% CI, 26.9-49.5\%; 153/406 patients; 9 studies; $\mathrm{I}^{2}=80.8 \%, \mathrm{p}<0.001$ ); and in Child-Pugh class C $31.9 \%$ (95\% CI, 19.6-45.3\%; 39/127 patients; 6 studies; $\mathrm{I}^{2}=$ $35.3 \%, p=0.17$ ) (Appendix S4B).

\subsubsection{Primary analysis: $D$-dimer accuracy in high-risk patients}

One study did not report the accuracy of D-dimer in the overall enrolled population but separately for different Child-Pugh classes [21], thus 11 studies were analysed for D-dimer accuracy (Fig. 4). D-dimer was positive in 344 (TP) out of 412 patients with objectively confirmed SVT, corresponding to a bivariate weighted mean sensitivity of $96 \%$ (95\% CI, 72-100\%). D-dimer was negative in 375 (TN) out of 752 patients in whom SVT was objectively ruled out, corresponding to a bivariate weighted mean specificity of $25 \%$ (95\% CI, 5-67\%). The positive likelihood ratio was $1.3(95 \% \mathrm{CI}, 0.9-1.9)$ and the negative likelihood ratio was 0.16 (95\% CI, 0.03-0.84). D-dimer showed moderate accuracy, as evidenced by the area under the ROC curve which was 0.80 (95\% CI, 0.76-0.83; $\mathrm{I}^{2}=99 \%, p<0.001$; Fig. 5).

Considering the weighted mean prevalence of SVT in the included studies (33.4\%) as pre-test probability, the Fagan plot (Fig. 6A) showed a post-test probability of SVT of $39 \%$ when D-dimer is positive and a post-test probability of $7 \%$ when D-dimer is negative. The probability modifying plot (Fig. 6B) showed that the D-dimer unconditional NPV was $85 \%$ (95\% CI, 53-100\%) and the unconditional PPV was 56\% (95\% CI, 43-68\%).

\subsubsection{Results of sensitivity and subgroups analyses and meta-regression}

Results of sensitivity and subgroup analysis are presented in Appendix S5. The 95\% CI of the sensitivity and specificity were large and widely overlapping, due to limited number of studies included in these sub-analyses. In 7 studies that evaluated the development of SVT after surgical procedures [22-24,27,30-32] D-dimer weighted mean sensitivity was $99 \%$ (95\% CI, 60-100\%) and weighted mean specificity was 9\% (95\% CI, 0-81\%). Conversely, in 4 studies evaluating cirrhotic or HCC patients without any recent surgery [25,26,28,29] D-dimer 


\begin{tabular}{|c|c|c|c|c|c|c|c|}
\hline \multirow[b]{2}{*}{ STUDY } & \multicolumn{4}{|c|}{ RISK OF BIAS } & \multicolumn{3}{|c|}{ APPLICABILITY CONCERNS } \\
\hline & $\begin{array}{c}\text { PATIENT } \\
\text { SELECTION }\end{array}$ & $\begin{array}{l}\text { INDEX } \\
\text { TEST }\end{array}$ & $\begin{array}{l}\text { REFERENCE } \\
\text { STANDARD }\end{array}$ & $\begin{array}{c}\text { FLOW } \\
\text { AND } \\
\text { TIMING }\end{array}$ & $\begin{array}{l}\text { PATIENT } \\
\text { SELECTION }\end{array}$ & $\begin{array}{c}\text { INDEX } \\
\text { TEST }\end{array}$ & $\begin{array}{l}\text { REFERENCE } \\
\text { STANDARD }\end{array}$ \\
\hline \multicolumn{8}{|c|}{ Patients with liver cirrhosis } \\
\hline $\begin{array}{l}\text { Fimognari, } \\
2005\end{array}$ & (;) & : & : & ;) & ;) & 2: & 2 \\
\hline $\begin{array}{c}\text { Zhang, } \\
2013 \\
\end{array}$ & 웅 & : & $?$ & : & ;) & : & (:) \\
\hline $\begin{array}{c}\text { Dai, } \\
2015 \\
\end{array}$ & (:) & ;) & $?$ & ;) & (-) & ;); & ;) \\
\hline $\begin{array}{l}\text { Wosiewicz, } \\
2016\end{array}$ & & : & $?$ & $?$ & ;) & 웅 & ;) \\
\hline \multicolumn{8}{|c|}{ Patients with hepatocellular carcinoma } \\
\hline $\begin{array}{c}\text { Malaguarnera, } \\
2018\end{array}$ & & (;) & $?$ & ? & ;) & ;:) & ;): \\
\hline \multicolumn{8}{|c|}{ Post-surgical patients } \\
\hline $\begin{array}{c}\text { Stamou, } \\
2006\end{array}$ & (-) & $?$ & 웅 & 웅 & ;): & $?$ & 웅 \\
\hline $\begin{array}{l}\text { Deng, } \\
2007 \\
\end{array}$ & 20 & ;): & : & : & ;) & ;) & : \\
\hline $\begin{array}{l}\text { Wang, } \\
2010\end{array}$ & : & ;) & ;) & 웅 & ;) & ;:) & ;:) \\
\hline $\begin{array}{l}\text { Fei, } \\
2016\end{array}$ & 웅 & ;) & $?$ & 웅 & ;) & ;) & ;) \\
\hline $\begin{array}{l}\text { Wei, } \\
2018 \\
\end{array}$ & : & ;) & : & : & ;) & ;) & (2) \\
\hline $\begin{array}{l}\text { Guo, } \\
2019 \\
\end{array}$ & : & ;:) & : & : & ;) & ;) & : \\
\hline $\begin{array}{c}\text { Takata, } \\
2021\end{array}$ & & ;); & $?$ & : & ;) & ;): & ;:) \\
\hline
\end{tabular}

Legend: - Low Risk (2)High Risk ?Unclear Risk

Fig. 2. Risk of bias of the included studies.

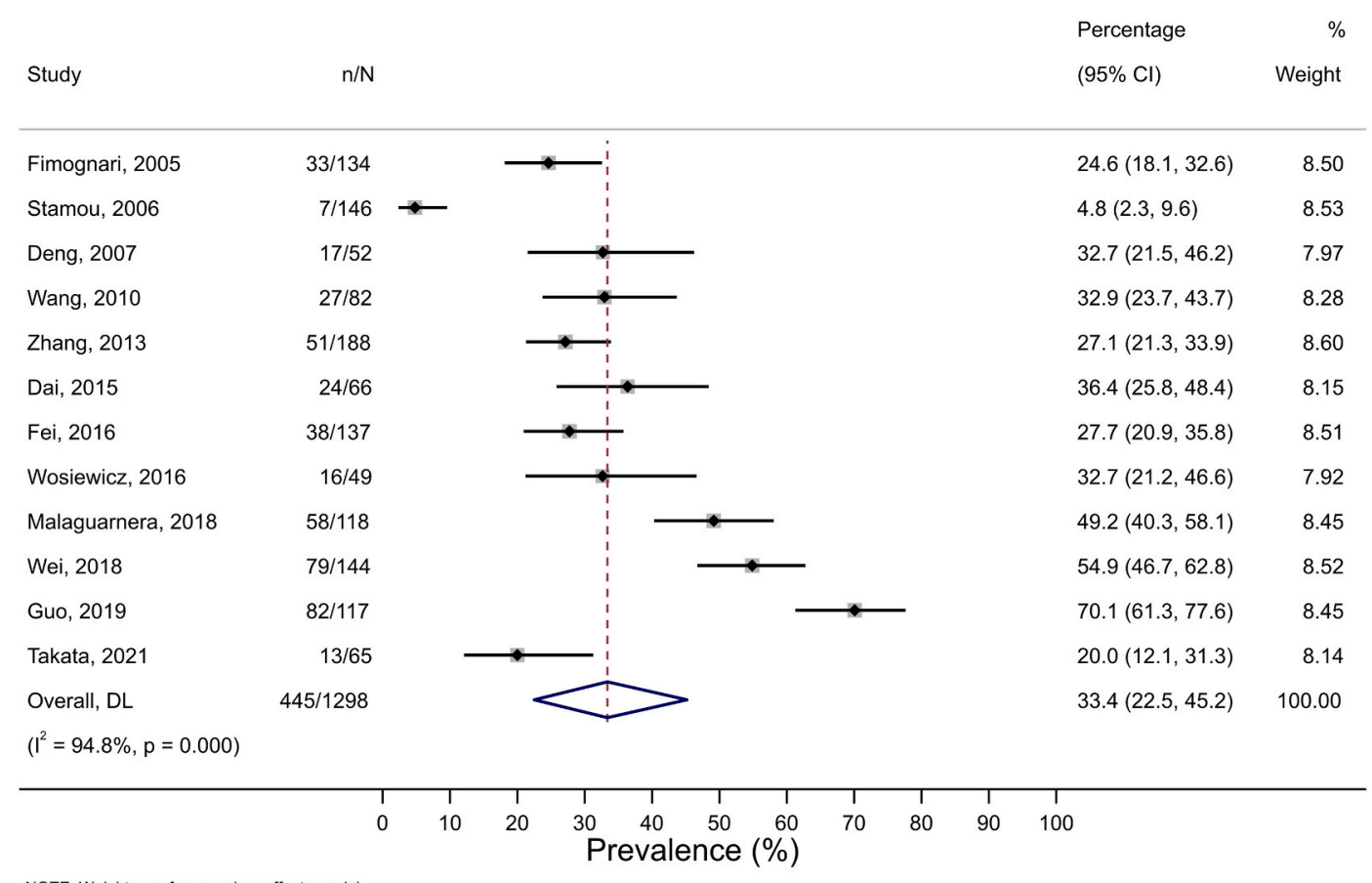

NOTE: Weights are from random-effects model

Fig. 3. Weighted mean prevalence of splanchnic vein thrombosis in high-risk patients from the included studies. 

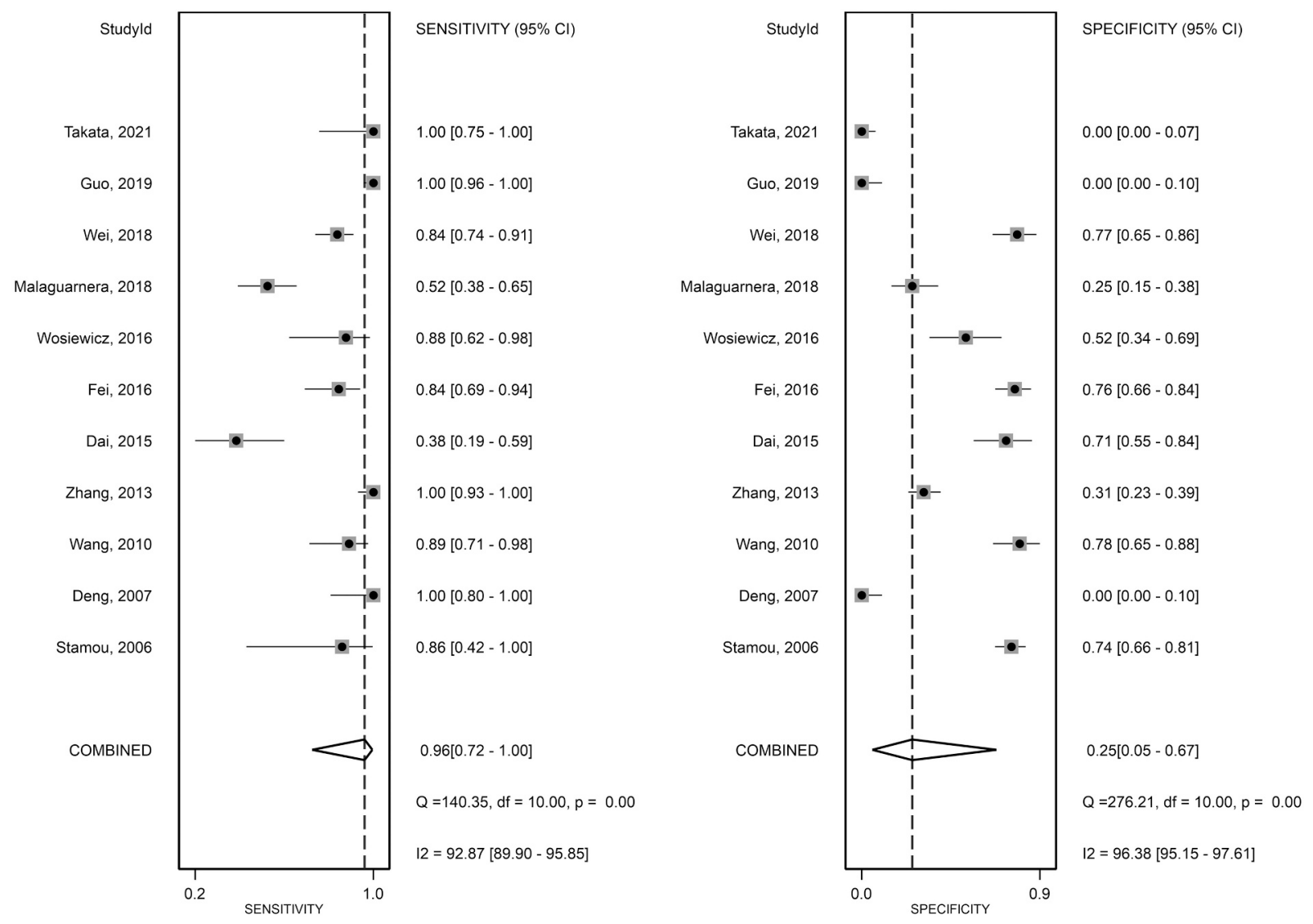

Fig. 4. Forest plot showing sensitivity and specificity in the included studies.
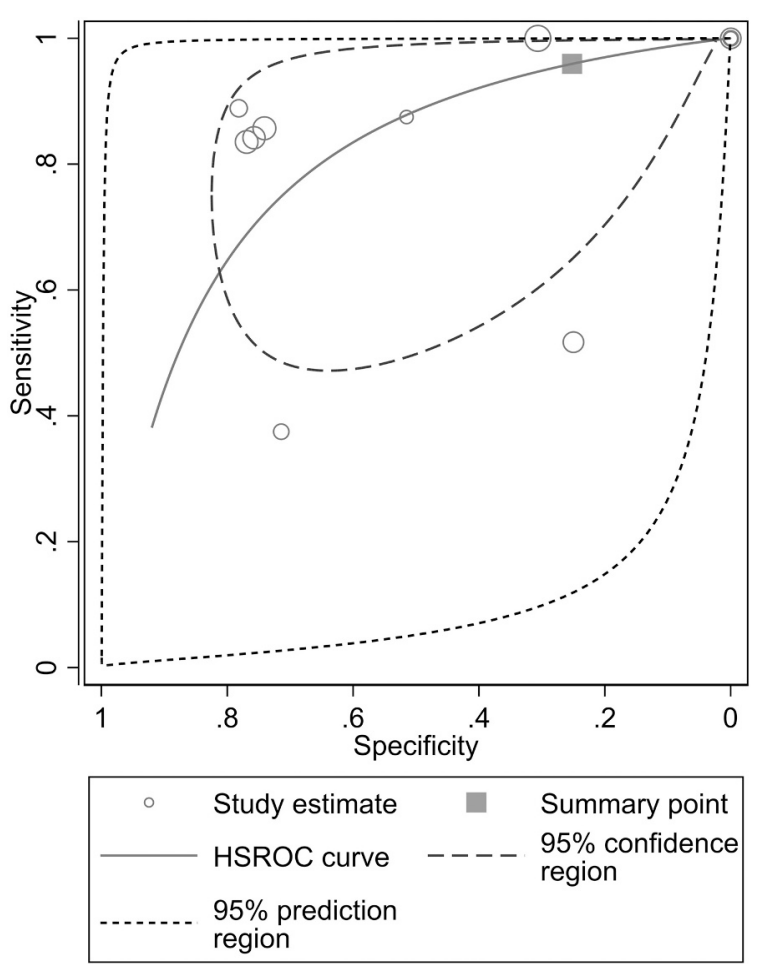

Fig. 5. Hierarchical summary receiver operating characteristics curve of the diagnostic accuracy of D-dimer for splanchnic vein thrombosis. weighted mean sensitivity was $84 \%$ (95\% CI, 32-98\%) and weighted mean specificity was $44 \%$ (95\% CI, 26-63\%). Of note, all the studies evaluating post-surgical patients used D-dimer manufacturers' thresholds, while studies evaluating non-surgical cirrhotic patients used mainly post-hoc optimal thresholds. In 3 studies evaluating post-hoc optimal cut-offs $[25,26,28]$ D-dimer weighted mean sensitivity was 93\% (95\% CI, 49-99\%) and weighted mean specificity was 50\% (95\% CI, 31-69\%); whereas in 9 studies evaluating manufacturer's cut-offs [22-24,26,27,29-32] D-dimer weighted mean sensitivity was 94\% (95\% CI, 64-99\%) and weighted mean specificity was 16\% (95\% CI, $1-75 \%)$.

Results of the meta-regression are reported in Appendix S6. Only the subgroup analysis by different population (surgical vs non-surgical patients) was associated with statistically significant different sensitivities $(p<0.001)$, while no differences of specificities were identified.

\subsection{Publication bias}

There were no published studies enrolling patients with clinically suspected SVT or patients at low risk of SVT. In high-risk patients, there was no evidence of publication bias on the Deeks' Funnel Plot $(p=0.31$, Appendix S7).

\section{Discussion}

In this systematic review, the accuracy of D-dimer for the diagnosis of SVT was evaluated. We estimated a weighted mean sensitivity of $96 \%$ (95\% CI, 72-100\%) and a weighted mean specificity of $25 \%$ (95\% CI, 5-67\%), suggesting that D-dimer might have high sensitivity for the exclusion of SVT in high-risk patients. However, our results should be interpreted with caution due to the high risk of bias and the heterogeneity in the published studies. 
A

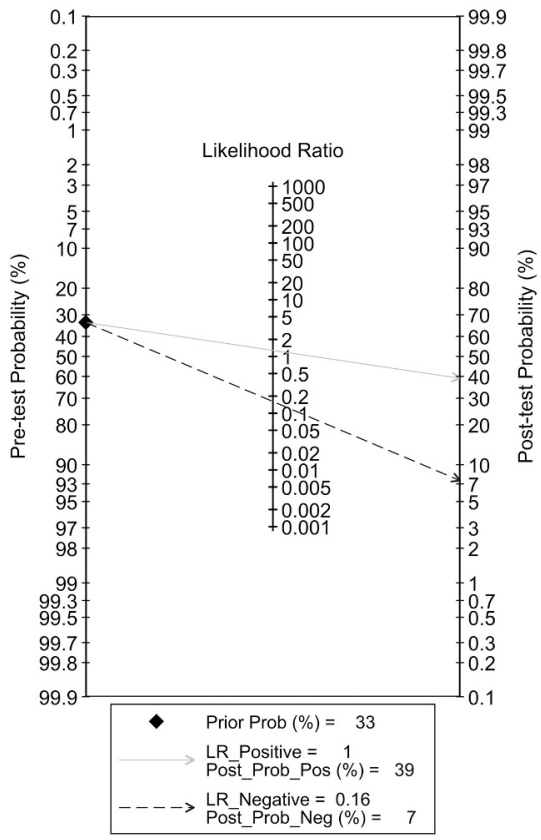

B

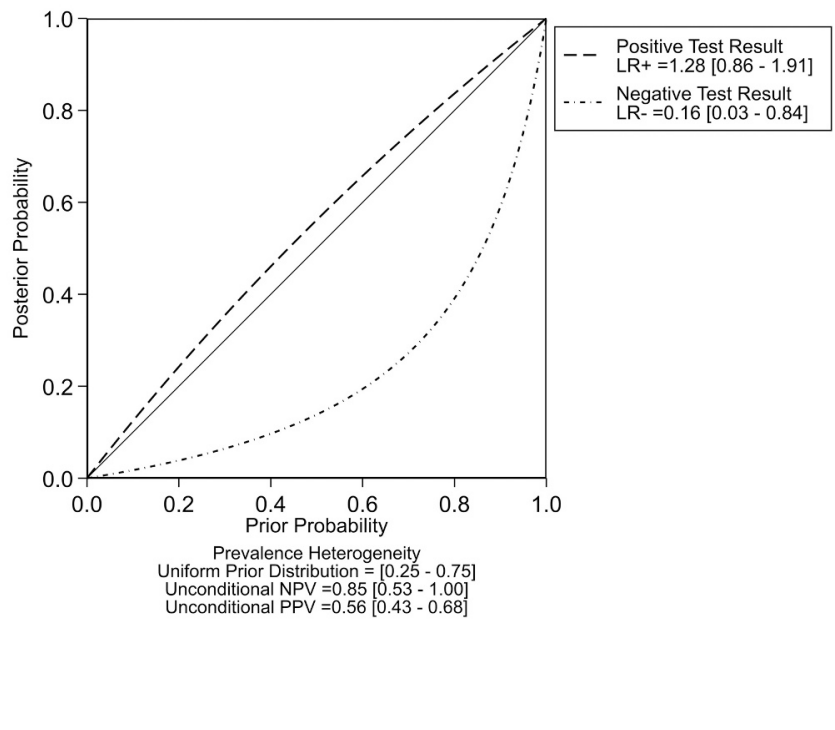

Fig. 6. Fagan plot (A) and probability modifying plot (B) showing the relationship between pre-test probability and post-test probability.

Despite the fact that our search strategy was developed with the aim to evaluate the accuracy of D-dimer for the diagnosis of SVT in different populations, we found no published studies evaluating patients at low risk of SVT (such as those presenting to the Emergency Department), nor studies evaluating patients with clinical suspicion of SVT, in whom Ddimer may have higher sensitivity and may be more useful in clinical practice. The combination of low pre-test probability with negative Ddimer is recommended by several guidelines to rule out some major vascular disorders, such pulmonary embolism and aortic dissection $[2,36,37]$. However, we could summarise data only for patients with major risk factors for SVT (patients at high risk of SVT), such as abdominal surgery [22-24,30-32,34], liver cirrhosis [21,23-28,30,31], and HCC $[29,32]$. In addition, we did not find any study evaluating the use of D-dimer for hepatic vein thrombosis, the major cause of the BuddChiari syndrome. In fact, all the retrieved studies considered thrombosis of the portal venous system, involving portal, mesenteric, and splenic veins. The prevalence of SVT in the included studies was $33.4 \%$, which was almost double than previous reported in similar high risk patient groups. For instance, Violi et al. described a prevalence of PVT of $17 \%$ in cirrhotic patients overall, corresponding to $11.3 \%$ in Child-Pugh A class, $24.8 \%$ in Child-Pugh B and $17.2 \%$ in Child-Pugh C [38]. A recently published study evaluating 486 consecutive laparoscopic splenectomies reported post-operative portal vein system thrombosis in $19.8 \%$ of cases [39]. The high prevalence of SVT together with the observational design of the included studies indicate that there might be a bias in the enrolled population, suggesting that D-dimer was tested in patients more likely to develop SVT among those at high risk. In fact, a higher prevalence increases the PPV and decreases the NPV [40], but sensitivity and specificity might also be influenced by disease prevalence [41].

While D-dimer is widely used for the exclusion of DVT and PE $[2,4,6]$, its role in the diagnosis of SVT is still unclear. Previously, the meta-analysis by Dai et al., published in 2015, evaluated the values of Ddimer in the development of SVT in patients with liver cirrhosis [35]. They performed an extensive search also into Chinese databases and included 21 studies with more than 2000 patients. D-dimer levels were considered as a continuous variable and they were significantly higher in patients with SVT [35]. Indeed, in the diagnostic algorithms for DVT and PE $[2,4,6]$ D-dimer is mainly used as a categorical result (positive vs. negative), using manufacturers' or eventually age-adjusted thresholds, rather than its absolute value. More recently, Ordieres-Ortega et al. performed a systematic review without meta-analysis on the predictive value of D-dimer for unusual site VTE, including 9 studies related to SVT [10]. After describing the main results, the authors highlighted the heterogeneity in the included studies.

We decided to perform a bivariate meta-analysis with the aim to calculate pooled sensitivity and specificity of D-dimer for SVT. As expected, specificity was low, but sensitivity was high, similar to the sensitivity for venous thrombosis at usual sites. However, several studies included in our meta-analysis $[21,25,26,28]$ used post-hoc D-dimer cutoffs, which were chosen as optimal cut-offs trying to optimise sensitivity and specificity or the area under the ROC curve. In addition, these thresholds were widely variable among the different studies (for instance, for Child-Pugh B could range from $225 \mathrm{ng} / \mathrm{mL}$ [21] to $3380 \mathrm{ng} /$ $\mathrm{mL}$ [28]). The use of different thresholds can explain the high heterogeneity and can also complicate the interpretation of the results.

Given the low quality of current available evidence, D-dimer should not be used as a stand-alone test in patients presenting to the Emergency Department with acute abdominal pain in order to exclude SVT and avoid further diagnostic imaging. Moreover, even if SVT could be safely excluded in patients with acute abdominal pain with a negative D-dimer in combination with a hypothetical low pre-test probability clinical assessment, the differential diagnosis of acute abdominal pain is so wide that specific abdominal imaging is usually mandatory to confirm or exclude other severe and potentially life-threatening disorders (e.g. ruptured aortic aneurysm, mesenteric ischaemia, peritonitis, ovarian torsion, and others) [42].

There might be a potential clinical use for D-dimer in cirrhotic patients. Even though they require periodical imaging to evaluate the progression of liver cirrhosis and its complications (such as HCC), Ddimer could be used in between abdominal imaging, probably establishing different cut-offs based on the degree of liver dysfunction. In addition, when a complication such as ascites or bleeding from esophageal varices occurs, a negative D-dimer may be useful to rule out PVT as underlying cause.

More controversial is the use of D-dimer after abdominal surgery, which is a well-known reason of elevated D-dimer values [1]. Recently, Takata et al. [32] reported that the postoperative/preoperative ratio of D-dimer was significantly higher in HCC patients who developed PVT after radical hepatectomy, suggesting that a ratio might be more accurate than the absolute D-dimer values. In particular, in this study a 
postoperative D-dimer at least 7.2 times the preoperative value was suggested as cut-off to raise the suspicion of SVT [32].

\subsection{Strengths and limitations}

The main limitations of this systematic review include the fact that the majority of included studies enrolled very specific patient populations, which restricts the generalisability of our results. Secondly, there was high heterogeneity among the different studies in the characteristics of the enrolled population, clinical settings, D-dimer assays and thresholds. In addition, several studies used D-dimer cut-offs which were derived post-hoc as optimal cut-offs, without external validation in independent patient samples. Thirdly, being a study-level meta-analysis, we could analyse aggregate data only: thus, we cannot provide conclusions for specific subgroups of patients or for other D-dimer cut-offs (e.g. age-adjusted D-dimer cut-offs). Nonetheless, the main strength of this study relies on the rigorous methodological approach, with systematic searches in both published and grey literature, and several steps performed in duplicate by two authors independently.

\subsection{Conclusions}

D-dimer seems to have high sensitivity also for the diagnosis of patients at high-risk for SVT. However, given the high risk of bias and high heterogeneity in the published literature on this topic, there is a strong need for more robust evidence. We suggest that future studies shall also include patients with clinical suspicion of SVT presenting at Emergency Department and shall evaluate D-dimer both as a continuous and categorical variable, using different threshold based on age and/or severity of liver dysfunction.

\section{Author contributions}

NR, AG, JCA were responsible for the conception and design of the study. NR, LMA, KV, AS acquired the data. NR performed the statistical analysis. All authors interpretated the data, drafted the manuscript, made critical revisions of the manuscript for important intellectual content, and provided final approval of the manuscript.

\section{Declaration of competing interest}

The authors declare the following financial interests/personal relationships which may be considered as potential competing interests: AS received a lecture fee from Werfen.

The other authors have no relevant conflicts of interest to declare in relation to this study.

No funding was provided for this study.

\section{Acknowledgments}

We are grateful to Drs. Xingshun Qi, Hideyuki Takata, Piotr Wosiewicz, Qingsheng Yu and Giulia Malaguarnera for kindly providing additional data. Preliminary findings from this study were presented as poster at the 2021 virtual congress of the International Society on Thrombosis and Hemostasis (ISTH).

\section{Appendix A. Supplementary data}

Supplementary data to this article can be found online at https://doi. org/10.1016/j.thromres.2021.09.016.

\section{References}

[1] S.S. Adam, N.S. Key, C.S. Greenberg, D-dimer antigen: current concepts and future prospects, Blood 113 (13) (2009) 2878-2887.

[2] S.V. Konstantinides, G. Meyer, C. Becattini, H. Bueno, G.J. Geersing, V.P. Harjola, et al., 2019 ESC guidelines for the diagnosis and management of acute pulmonary embolism developed in collaboration with the European Respiratory Society (ERS), Eur. Heart J. 41 (4) (2020) 543-603.

[3] G. Lippi, L. Bonfanti, C. Saccenti, G. Cervellin, Causes of elevated D-dimer in patients admitted to a large urban emergency department, Eur. J. Intern. Med. 25 (1) (2014) 45-48.

[4] S.M. Bates, R. Jaeschke, S.M. Stevens, S. Goodacre, P.S. Wells, M.D. Stevenson, et al., Diagnosis of DVT. Antithrombotic Therapy and Prevention of Thrombosis, 9th ed: American College of Chest Physicians Evidence-Based Clinical Practice Guidelines, Chest 141 (2 Suppl.) (2012) e351S-e418S.

[5] W. Ageno, G. Camporese, N. Riva, M. Iotti, E. Bucherini, M. Righini, et al., Analysis of an algorithm incorporating limited and whole-leg assessment of the deep venous system in symptomatic outpatients with suspected deep-vein thrombosis (PALLADIO): a prospective, multicentre, cohort study, Lancet Haematol. 2 (11) (2015) e474-e480.

[6] W. Lim, G. Le Gal, S.M. Bates, M. Righini, L.B. Haramati, E. Lang, et al., American Society of Hematology 2018 guidelines for management of venous thromboembolism: diagnosis of venous thromboembolism, Blood Adv. 2 (22) (2018) 3226-3256.

[7] F. Dentali, A. Squizzato, C. Marchesi, M. Bonzini, J.M. Ferro, W. Ageno, D-dimer testing in the diagnosis of cerebral vein thrombosis: a systematic review and a meta-analysis of the literature, J. Thromb. Haemost. 10 (4) (2012) 582-589.

[8] W. Ageno, N. Riva, S. Schulman, S.M. Bang, M.T. Sartori, E. Grandone, et al., Antithrombotic treatment of splanchnic vein thrombosis: results of an international registry, Semin. Thromb. Hemost. 40 (1) (2014) 99-105.

[9] N. Riva, W. Ageno, Clinical manifestations and imaging tools in the diagnosis of splanchnic and cerebral vein thromboses, Thromb. Res. 163 (2018) 252-259.

[10] L. Ordieres-Ortega, P. Demelo-Rodríguez, F. Galeano-Valle, B.M.M. Kremers, A. J. Ten Cate-Hoek, H. Ten Cate, Predictive value of D-dimer testing for the diagnosis of venous thrombosis in unusual locations: a systematic review, Thromb. Res. 189 (2020) 5-12.

[11] McInnes MDF, D. Moher, B.D. Thombs, McGrath TA, P.M. Bossuyt, the PRISMADTA Group, Preferred reporting items for a systematic review and meta-analysis of diagnostic test accuracy studies: the PRISMA-DTA statement, JAMA 319 (4) (2018) 388-396.

[12] P.F. Whiting, A.W. Rutjes, M.E. Westwood, S. Mallett, J.J. Deeks, J.B. Reitsma, et al., QUADAS-2: a revised tool for the quality assessment of diagnostic accuracy studies, Ann. Intern. Med. 155 (8) (2011) 529-536.

[13] D.A. Simonetto, A.K. Singal, G. Garcia-Tsao, S.H. Caldwell, J. Ahn, P.S. Kamath, ACG clinical guideline: disorders of the hepatic and mesenteric circulation, Am. J. Gastroenterol. 115 (1) (2020) 18-40.

[14] Higgins JPT, J. Thomas, J. Chandler, M. Cumpston, T. Li, M.J. Page, et al., Cochrane Handbook for Systematic Reviews of Interventions version 6.1 (updated September 2020): Cochrane. www.training.cochrane.org/handbook, 2020.

[15] J.B. Reitsma, A.S. Glas, A.W. Rutjes, R.J. Scholten, P.M. Bossuyt, A.H. Zwinderman, Bivariate analysis of sensitivity and specificity produces informative summary measures in diagnostic reviews, J. Clin. Epidemiol. 58 (10) (2005) 982-990.

[16] R.M. Harbord, P. Whiting, Metandi: meta-analysis of diagnostic accuracy using hierarchical logistic regression, Stata J. 9 (2009) 211-229.

[17] T.J. Fagan, Letter: nomogram for bayes theorem, N. Engl. J. Med. 293 (5) (1975) 257.

[18] J.J. Deeks, P. Macaskill, L. Irwig, The performance of tests of publication bias and other sample size effects in systematic reviews of diagnostic test accuracy was assessed, J. Clin. Epidemiol. 58 (2005) 882-893.

[19] B.A. Dwamena, R. Sylvester, R.C. Carlos, Midas: meta-analysis of diagnostic accuracy studies. http://fmwww.bc.edu/repec/bocode/m/midas.pdf, 2007. (Accessed 13 February 2021).

[20] J. Zamora, V. Abraira, A. Muriel, K. Khan, A. Coomarasamy, Meta-DiSc: a software for meta-analysis of test accuracy data, BMC Med. Res. Methodol. 6 (2006) 31.

[21] F.L. Fimognari, A. De Santis, C. Piccheri, R. Moscatelli, F. Gigliotti, A. Vestri, et al., Evaluation of D-dimer and factor VIII in cirrhotic patients with asymptomatic portal venous thrombosis, J. Lab. Clin. Med. 146 (4) (2005) 238-243.

[22] K.M. Stamou, K.G. Toutouzas, P.B. Kekis, S. Nakos, A. Gafou, A. Manouras, et al., Prospective study of the incidence and risk factors of postsplenectomy thrombosis of the portal, mesenteric, and splenic veins, Arch. Surg. 141 (7) (2006) 663-669.

[23] M.H. Deng, B. Liu, H.P. Fang, W.D. Pan, Z.F. Tang, P. Deng, et al., Predictive value of D-dimer for portal vein thrombosis after portal hypertension surgery in hepatitis B virus-related cirrhosis, World J. Gastroenterol. 13 (48) (2007) 6588-6592.

[24] L. Wang, G.J. Liu, Y.X. Chen, H.P. Dong, Y.Q. Zhang, L.X. Wang, Combined use of D-dimer and P-selectin for the diagnosis of splenic or portal vein thrombosis following splenectomy, Thromb. Res. 125 (5) (2010) e206-e209.

[25] D.L. Zhang, J.Y. Hao, N. Yang, Value of D-dimer and protein S for diagnosis of portal vein thrombosis in patients with liver cirrhosis, J. Int. Med. Res. 41 (3) (2013) 664-672.

[26] J. Dai, X. Qi, Y. Peng, Y. Hou, J. Chen, H. Li, et al., Association between D-dimer level and portal venous system thrombosis in liver cirrhosis: a retrospective observational study, Int. J. Clin. Exp. Med. 8 (9) (2015) 15296-15301.

[27] Y. Fei, G.Q. Zong, J. Chen, R.M. Liu, Evaluation of the value of d-dimer, P-selectin, and platelet count for prediction of portal vein thrombosis after devascularization, Clin. Appl. Thromb. Hemost. 22 (5) (2016) 471-475.

[28] P. Wosiewicz, M. Żorniak, M. Hartleb, K. Barański, M. Hartleb, M. Onyszczuk, et al., Portal vein thrombosis in cirrhosis is not associated with intestinal barrier disruption or increased platelet aggregability, Clin. Res. Hepatol. Gastroenterol. 40 (6) (2016) 722-729.

[29] M. Malaguarnera, S. Latteri, G. Bertino, R. Madeddu, V.E. Catania, G. Currò, et al., D-dimer plasmatic levels as a marker for diagnosis and prognosis of hepatocellular 
carcinoma patients with portal vein thrombosis, Clin. Exp. Gastroenterol. 11 (2018) 373-380.

[30] Y. Wei, X. Chen, H. Shen, W. Wu, G. Cao, W. Chen, et al., P-selectin level at first and third day after portal hypertensive splenectomy for early prediction of portal vein thrombosis in patients with cirrhosis, Clin. Appl. Thromb. Hemost. 24 (9 Suppl.) (2018) 76S-83S.

[31] B. Guo, J. Pan, Y. Shen, Q. Zhang, Z. Wang, L. Huang, et al., Platelet's rule of change and clinical significance before and after splenectomy, Am. Surg. 85 (11) (2019) 1288-1293.

[32] H. Takata, A. Hirakata, J. Ueda, T. Yokoyama, H. Maruyama, N. Taniai, et al., Prediction of portal vein thrombosis after hepatectomy for hepatocellular carcinoma, Langenbecks Arch. Surg. (2021 Feb 27), https://doi.org/10.1007/ s00423-021-02125-9.

[33] D. Zhang, J. Hao, N. Yang, Protein C and D-dimer are related to portal vein thrombosis in patients with liver cirrhosis, J. Gastroenterol. Hepatol. 25 (1) (2010) $116-121$.

[34] Y. Fei, G.Q. Zong, J. Chen, R.M. Liu, Evaluation the value of markers for prediction of portal vein thrombosis after devascularization, Ann. Hepatol. 14 (6) (2015) 856-861.

[35] J. Dai, X. Qi, H. Li, X. Guo, Role of D-dimer in the development of portal vein thrombosis in liver cirrhosis: a meta-analysis, Saudi J. Gastroenterol. 21 (3) (2015) $165-174$.

[36] R. Erbel, V. Aboyans, C. Boileau, E. Bossone, R.D. Bartolomeo, H. Eggebrecht, et al., 2014 ESC Guidelines on the diagnosis and treatment of aortic diseases: document covering acute and chronic aortic diseases of the thoracic and abdominal aorta of the adult. The Task Force for the Diagnosis and Treatment of Aortic Diseases of the European Society of Cardiology (ESC), Eur. Heart J. 35 (41) (2014) 2873-2926.

[37] P. Bima, E. Pivetta, P. Nazerian, M. Toyofuku, R. Gorla, E. Bossone, et al., Systematic review of aortic dissection detection risk score plus D-dimer for diagnostic rule-out of suspected acute aortic syndromes, Acad. Emerg. Med. 27 (10) (2020) 1013-1027.

[38] F. Violi, R.G. Corazza, S.H. Caldwell, F. Perticone, A. Gatta, M. Angelico, et al., Portal vein thrombosis relevance on liver cirrhosis: italian venous thrombotic events registry, Intern. Emerg. Med. 11 (8) (2016) 1059-1066.

[39] X. Fu, Z. Yang, S. Tu, W. Xin, H. Chen, X. Li, et al., Short- and long-term outcomes of 486 consecutive laparoscopic splenectomy in a single institution, Medicine (Baltimore) 100 (13) (2021), e25308.

[40] S. Tenny, M.R. Hoffman, Prevalence. 2021 May 30, in: StatPearls [Internet], StatPearls Publishing, Treasure Island (FL), 2021 Jan.

[41] M.M. Leeflang, P.M. Bossuyt, L. Irwig, Diagnostic test accuracy may vary with prevalence: implications for evidence-based diagnosis, J. Clin. Epidemiol. 62 (1) (2009) 5-12.

[42] F. Vaghef-Davari, H. Ahmadi-Amoli, A. Sharifi, F. Teymouri, N. Paprouschi, Approach to acute abdominal pain: practical algorithms, Adv. J. Emerg. Med. 4 (2) (2019), e29. 